\title{
THE LABOUR SPAIN COMMITTEE: LABOUR PARTY POLICY AND THE SPANISH CIVIL WAR*
}

\author{
C. FLEAY AND M. L. SANDERS \\ Middlesex Polytechnic
}

\begin{abstract}
We failed wholly in our objective which was to persuade the National Executive and the Labour movement as a whole to challenge the government dramatically on its attitudes and policies, so-called non-intervention and neutrality in the Spanish War. ${ }^{1}$
\end{abstract}

Such was the frank but despairing assessment of J. C. Pole, secretary of the Labour Spain Committee. This organization - with others - articulated the protest of Labour party members and followers against the attitudes and approach of the party leadership towards the Spanish Civil War. The history of this particular committee, however, illuminates not only the internal divisions of the Labour party during the period $193^{6-9}$; it also helps to explain why an impressive expression of discontent from the Labour movement as a whole was effectively ignored by the policy makers of the Labour party. ${ }^{2}$

The outbreak of the Spanish Civil War in July $193^{6}$ brought an immediate pledge of support from Clement Attlee, the leader of the Labour party, for the Spanish Republican government against the Nationalist uprising. ${ }^{3}$ However, on 2 August the leader of the Popular Front government of France, Léon Blum, proposed a non-intervention agreement which would prohibit the sale of arms to either side in the war. Such a policy was welcomed by the National government in Britain, which, indeed, had helped initiate the proposal. With parliament in recess, the Labour party leadership accepted these developments and at the annual Labour party conference at Edinburgh in October 1936 received cautious approval from the Labour movement for the idea of non-intervention.

Approval, however, could not disguise the gulf which separated the party leaders from the rank and file membership in the constituency parties. The latter considered

* The authors would like to acknowledge the following: Austen Albu who discussed the article with them and who gave access to his private papers, including his unpublished manuscript, 'Back-bench technocrat'; Dr Stephen Doree and Professor Anthony Adamthwaite for their comments on the original draft.

$1 \mathrm{~J}$. C. Pole, brief historical note to the papers of the $\mathrm{L}$ (abour) $\mathrm{SP}$ (ain) $\mathrm{C}$ (ommittee), Ch(urchill) Col(lege), Cambridge, LSPC/1/1.

2 Donald S. Birn draws a parallel between the experience of the Labour party and that of the League of Nations Union, where policy towards Spain was concerned: 'In both cases rank and fle opinion was Republican and impatient with a leadership which seemed as dilatory as the Government itself.' Donald S. Birn, The League of Nations Union (Oxford, 1981), p. I 86. For a basic account of Labour party policy towards the Spanish Civil War see K. W. Watkins, Britain Divided. The effect of the Spanish Civil War on British political opinion (London, 1963), ch. $v$ and John F. Naylor, Labour's international policy: the Labour party in the 1930s (London, 1969).

- See Hugh Thomas, The Spanish Civil War (Penguin, 1977, 3rd edn), p. 344. 
their views inadequately represented on the National Executive of the Labour party and their dissatisfaction expressed itself in the formation of the Home Counties Labour Association, whose secretary Ben Greene helped to organize the Provisional Committee of Constituency Labour parties at the Edinburgh conference. Stafford Cripps was appointed its first chairman." This committee challenged the dominance of the trade unions on the National Executive by mounting a nationwide campaign to increase constituency representation.

Labour party policy towards the Spanish conflict became a focal point for the campaign and led to the emergence of the Labour Spain Committee at a conference, summoned by the executive committee of the Home Counties Labour Association, at the Conway $\mathrm{Hall}$ in London on 13 March $1937 .{ }^{5}$ Indeed, the latter had already established a subcommittee on Spain to conduct a campaign of support throughout the home counties for the Spanish government." The Labour Spain Committee, consisting of C. J. Garnsworthy (also chairman of the Home Counties Labour Association), J. G. Pole, Austen Albu the treasurer, Mollie Millar and Sybil Wingate, was directed to work with the subcommittee in the pursuit of three main objectives. These were first, to urge the National Executive of the Labour party to call a conference of the whole Labour movement to reassess the Spanish situation and receive fresh instructions; secondly, to initiate a nationwide campaign to compel the National government to restore the rights of the Spanish government to buy arms; and thirdly, to co-ordinate all anti-fascist groups working to help Republican Spain into a single movement. The March 1937 conference was dissatisfied with the acceptance of non-intervention by the Labour party at Edinburgh:

The Conference felt that this attitude was a complete misrepresentation of the vast majority of the labour movement and that in view of the failure of the leadership it had become urgent for the rank and file to take the initiative.

In pursuing its aims, the Labour Spain Committee was immediately disadvantaged by the opposition of the Labour party leadership to constituency party organizations as well as any organization associated with the idea of a popular front government in Britain. One of the leading protagonists of the idea was Stafford Cripps. Thus the constituency party movement was immediately compromised in the eyes of the party leadership and so by inference was the Labour Spain Committee. The position of the latter was made more difficult when $\mathbf{H}$. N. Brailsford replaced Garnsworthy as chairman soon after its formation. Brailsford's commitment to the idea of a popular front government was well known. He preached the theme regularly through his articles for Reynolds News - the paper of the Co-operative movement which frequently antagonized the National Executive. ${ }^{8}$ In 1938 Brailsford and, by association the committee, was closely linked with the United Peace Alliance, a successor to the Unity Campaign which Cripps had led in an effort to unite the

4 For further details of the $\mathrm{H}$ (ome) $\mathrm{C}$ (ounties) $\mathrm{L}$ (abour) A(ssociation) see Ben Pimlott, Labour and the left in the 1930s (Cambridge, 1977), Pp. $118-21$.

${ }^{5}$ Report on conference, 13 Mar. 1937, LSPC papers, LSPC/1/2.

- Minutes of the executive committee, HCLA, Garnsworthy papers, B(ritish) L(ibrary) of $\mathrm{P}$ (olitical and E(conomic) S(cience), Coll. Misc. 540, fo. 2.

' Report on March conf., LSPC papers, LSPC/1/2.

${ }^{8} \mathrm{H}$. N. Brailsford had been editor of the New Leader, the paper of the Independent Labour party, of which he was a member from 1922 to 1926 . He was a member of the Socialist League and was known prior to 1936 for his sympathetic analysis of the Soviet Union. 
Labour party, the Independent Labour party and the Communist party. ${ }^{9}$ In October 1938 the Labour Spain Committee was still calling for the 'union of all the progressive forces in the country for the defence of democracy at home and abroad'. ${ }^{10}$

Members of the committee were not unaware of the implications of such links and Pole recognized, as Greene had before him, ${ }^{11}$ that the question of the popular front could confuse the issue. He wrote to Cripps:

there is uncertainty among the DL (divisional Labour) Parties as to the Popular Front and if that were made the issue the outcome might be doubtful. On the other hand, the evidence of a desire for action in Spain is very great. Parties that are doubtful about the former, are prepared to go to any length on the latter issue. There is of course some illogicality in their position, nevertheless, the fact is important. ${ }^{12}$

Some attempt to distinguish between the two might have assuaged some of the fears of the Labour party leadership, but in practice nothing was done and the Labour Spain Committee was viewed by them as a threat to the unity of the Labour party.

The sensitivity of the party leaders towards the notion of a popular front stemmed from various sources. One undoubtedly was the memory of the painful split of 193 I and the need that was felt to build up the strength of the Labour party. Thus Hugh Dalton wrote to Kingsley Martin, editor of the New Statesman, 'as to Spain, I found last year that many more people were focusing on that rather than strengthening the Labour party...' ${ }^{13}$ A second objection was that a popular front movement automatically involved the communists. The Labour party repeatedly rejected efforts by the British Communist party to affiliate and ruled against co-operation at any level, ${ }^{14}$ carrying its opposition to the Labour Socialist International. At a meeting of the latter and the International Federation of Trade Unions in London on Io March 1937, British Labour party representatives expressed regret at attempts to arrange a conference for all parties interested in supporting Republican Spain. This was because it ' had the effect of diverting attention from the real issue of helping Spain and concentrating it on the controversial issue of the United Front'.$^{15}$

It is ironic that the policy of non-intervention accepted at Edinburgh in October 1936 was justified as a means of supporting and defending the Popular Front government of France. A deputation of W. Gillies, George Hicks and Hugh Dalton met Léon Blum in September $193^{6}$ and accepted his warning that a more positive policy of aid towards Republican Spain might provoke civil war in France and with it, the collapse of the socialist government. ${ }^{16}$

- Report by J. S. Middleton to N(ational) E(xecutive) $\mathrm{C}$ (ommittee) of the Labour party, 12 Apr. 1938, NEC minutes, BLPES, R/B7 (Microfiche, Harvester Press).

10 Draft letter to divisional Labour parties, LSPC papers, LSPC/ $/ 7$. There was informal co-operation at a local level but no formal links were established with the chief proponent of the popular front, the Left Book Club.

11 See report to P[rovisional] C[ommittee] of C[onstituency] L[abour] P[arties], in Feb. 1937, Cripps papers, Nuf[field] Col[lege], Oxford, 505. See also Pimlott, Labour and left, pp. 98-108. 12 Pole to Cripps, 29 Apr. 1938, LSPC papers, LSPC/ $1 / 4$.

13 Dalton to Martin, 26 Oct. 1937, Dalton papers, BLPES, $5 / 3$.

14 Memo. by J. S. Middleton, Jan. 1937, Middleton papers, L(abour) P(arty) A(rchives), London, box I I JSM/CP/145. See also Henry Pelling, The British Communist party. A historical 'profile (London, 1975), p. 88 and 'Labour-Communist relations 1920-1939', Our history, v (1957), 33-7.

is Account of L[abour] S[ocialist] I[nternational] and I[nternational] F[ederation] of T[rade] U[nions], IO-I I Mar. 1937, Report of 37th annual conference of the Labour party, Oct. 1937 at Bournemouth, p. 9, Labour Party Library. ${ }^{16}$ Diary entry, 10 May 1939, Dalton papers. 
In addition, the Labour party leadership argued that the British public was not ready for war. As Citrine, from the chair, told a meeting of the Labour Socialist International:

It should not be assumed that in Great Britain public opinion had taken such definite sides as to the rights and wrongs of the Spanish conflict as might have been done in other countries. In Great Britain the position was that no Government would be able to secure public support for any action which the people believed would lead to war. ${ }^{17}$

Linked to this view was a party policy which opposed rearmament in Britain and which rendered problematic a call for arms for Spain. As Dalton informed Kingsley Martin, 'I was not going to put myself in the untenable position, as I deemed it, of calling for arms for Spain, but no arms for my own country. ${ }^{18}$

The outcome of these arguments was a very defensive speech by Arthur Greenwood, deputy leader of the Labour Party, at the Edinburgh conference which recognized that the non-intervention policy was a 'very bad second best'. ${ }^{10}$ His speech aroused furious criticism, particularly from Sir Charles Trevelyan and Aneurin Bevan, and only after a fractious debate was party policy accepted. ${ }^{20}$

Almost immediately, however, the party leadership began to modify their position. Attlee and Greenwood were dispatched to London to discuss the Spanish situation with the government and it was agreed at a joint meeting of the National Council, with representatives from the National Executive committee, the parliamentary Labour party and the General Council of the Trades Union Congress, that a resolution be submitted to the conference to recommend that if serious breaches of the non-intervention agreement occurred, then the Spanish government should be permitted to buy arms. ${ }^{21}$ By the end of October $193^{6}$ the National Council agreed unanimously that the full commercial rights of the Spanish government should be restored. ${ }^{22}$ Yet at a meeting of the National Executive in January I937, a proposal by Herbert Morrison ${ }^{23}$ that the National government should be pressed to agree to the exportation of arms and to grant licences for that purpose was defeated. ${ }^{24}$ The parliamentary party leaders continued to press the government to make nonintervention work.

It was only at the Geneva conference of the Labour Socialist International and the International Federation of Trade Unions in June 1937 that the British delegation agreed to assist the Spanish government to recover its political and territorial independence, enforce the restoration of its commercial liberty and make

17 Report of LSI/IFTU meeting, 4 Dec. 1936, Spanish Civil War, LPA, SCW/5/3.

18 Dalton to Martin, 26 Oct. 1937, Dalton papers, $5 / 3$ :

19 Address to conference, 5 Oct. 1936, Report of 36 th annual conference of Labour party, p. 169 .

20 Only after the debate were the addresses of two Spanish delegates heard, after which the whole conference stood to sing the 'Red Flag'. One historian claims: 'It was known that two delegates were on their way from Spain to the conference. On with the debate, then, and get it over before the delegates arrive.' Eric Estorick, Stafford Cripps (London, 1949), p. I50. A pamphlet The agony of Spain containing their speeches was published in Oct. 1936 by Transport House following a conference decision.

${ }^{21}$ Minutes of the N[ational] C[ouncil] of L[abour], 8 Oct. 1936, NEC mins.

22 Minutes of NCL, 28 Oct. 1936, NEC mins.

23 Herbert Morrison was a consistent opponent of non-intervention, but exercised restraint in public debate because he had no wish to fuel the popular front argument - see Bernand Donoughue and G. W. Jones, Herbert Morrison: portrait of a politician (London, 1973), p. 259.

248 Jan. 1937, NEG mins. 
an unquestioning commitment of solidarity with the cause of the Republic. ${ }^{25}$ This commitment was confirmed by the National Council of Labour on $23 \mathrm{June} 1937 .{ }^{26}$ In effect, the Labour party had decided to reverse the decision of the 1936 Edinburgh conference and oppose non-intervention.

This change of policy might be considered to have removed the reasons behind the Labour Spain Committee campaign, but there were suspicions that the Labour party leadership was not sincere in its change of mind. Observing the house of commons debates on 25 June 1937, Brailsford believed that various speakers on the Labour side seemed to want to continue non-intervention in disguise by referring the Spanish issue to the League of Nations. The chairman of the Labour Spain Committee therefore advocated the continuation of the campaign through public meetings and demonstrations. ${ }^{27}$

The National Executive had ignored Brailsford and his committee from the very beginning. On 24 March 1937 it was decided not to receive a deputation from the Home Counties Labour Association to discuss the Spanish conflict. ${ }^{28}$ However, it was not oblivious to the feelings of the rank and file and sought to remove discontent through organizational reform. This became clear at the annual party conference at Bournemouth in October 1937, when much of the sting of the constituency parties' campaign was removed by a resolution giving them seven directly elected seats on the National Executive. ${ }^{20}$ The Labour party secretary, J. S. Middleton, followed this up in $193^{8}$ by inviting the Home Counties Labour Association to disband and become a propaganda organization under party rules. The proposal was rejected, ${ }^{30}$ but the intention was clear.

The divisions of the Edinburgh conference over the Spanish issue were further healed at Bournemouth. Sir Charles Trevelyan, a bitter critic in 1936, welcomed the change that had occurred in June 1937. However, he believed that resolutions were not enough to convince the National government to change its policies. He therefore proposed a declaration of solidarity with Republican Spain and called upon the National Executive to launch a national campaign to compel the government to abandon its policy ${ }^{31}$ Cripps pursued this at a meeting of the National Executive and suggested that a special committee be created to carry out a campaign to aid Spain. ${ }^{32}$ As a result the international subcommittee was deputed to appoint one. Thus the Spain Campaign Committee came into being. ${ }^{33}$

The new committee had as its chairman George Dallas and its members were Cripps, Joseph Henderson, Stanley Hirst, James Walker and Ellen Wilkinson. ${ }^{\text {sa }}$ There is no direct evidence to suggest that it was established as an antidote to the Labour Spain Committee, but it was undoubtedly designed to stifle the agitation that bodies such as the latter were conducting. Immediately, the Spain Campaign Committee set in motion a series of meetings and demonstrations which were to begin

25 Report by W. Gillies, secretary to the International department of the Labour party, to NEC, 23 Jun. 1937, NEC mins.

26 NEC mins.

27 Chairman's notes, undated, LSPC papers, LSPC/ $1 / 2 . \quad 28$ NEC mins.

2o See Henry Pelling, A short history of the Labour party (London, I96I), p. 83.

20 May 1938, NEC mins.

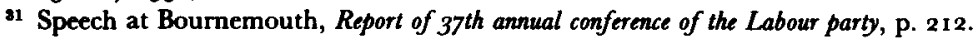

32 Oct. 1937, NEC mins. 33 I Nov. 1937, NEC mins.

24 In addition there were a number of co-opted members, a list of which reveals how radical critics of policy on Spain were drawn into the organizational net - see NEC mins, I Nov. 1937. 
in Manchester on 14 November 1937 and culminate in a mass meeting at the Albert Hall on 19 December 1937 . This policy was sustained into $193^{8}$ with May Day demonstrations, a 'Spanish Weekend' on 21 and 22 May 1938, and a Trafalgar Square rally on 17 July 1938 marking the outbreak of the civil war. Its campaign called for the right of Republican Spain to buy arms, demanded the withdrawal of foreign volunteers and argued against the granting of belligerent rights to General Franco and the Nationalists. Yet its document 'Our Appeal' made little specific reference to the policy of non-intervention or to a political campaign against the National government. ${ }^{35}$ As a 'political animal' the Spain Campaign Committee fell far short of the expectations of Sir Charles Trevelyan and many others.

The main thrust of the committee's work was that of relief, and it became a focal point for humanitarian aid to Spain which had been undertaken since the beginning of the civil war, initially through the International Solidarity Fund and then through a variety of organizations. ${ }^{36}$ The most advertised of its campaigns was the 'Milk for Spain' programme, which involved the purchase of tokens through Co-operative societies. The justification for this was strategic. It was argued that the greatest threat to the Spanish Republic was starvation as a result of a Nationalist blockade. Dalton made this point at Birmingham in November 1937 :

For the Spanish people the right to buy arms is not more important than the power to buy food. Those who are helping to send food to Spain from this country are not only performing a work of mercy but a work of self-defence against the ever growing world menace of totalitarian tyranny. ${ }^{\text {.7 }}$

In 1939, however, Cripps argued that food ships and medical supplies alone could not save Spain. Rather,

they provide the best form of escape mechanism for hundreds of thousands of people who are deeply concerned on the Spanish situation (sic) and they allow the Government to enjoy a vicarious humanitarianism. ${ }^{38}$

Yet as a member of the Spain Campaign Committee, Cripps appears to have been mute on the topic, possibly because he rarely attended its meetings. Sybil Wingate was not silent however. She wrote to Cripps in November 1937 praising the committee for its stance on relief, but she argued that it was failing politically by not exerting sufficient pressure on the government. ${ }^{39}$ In December the committee received from her a memorandum which advocated a more 'political' campaign, but consideration of the issue was held over until the New Year. ${ }^{40}$ However, Sybil Wingate resigned early in $193^{8}$ from the Spain Campaign Committee and there is no confirmation in its sparse minutes that the memorandum was ever discussed.

The committee also resisted taking any action on a memorandum submitted by Geoffrey Pyke, secretary of Voluntary Industrial Aid for Spain. ${ }^{41}$ This body came into being after the Trade Union Congress of September 1937 when Sir Walter Citrine urged the unions to take the lead in action on Spain. ${ }^{42}$ A group of trade union

\footnotetext{
35 Labour party circular of S[pain] C[ampaign] G[ommittee], Spanish Civil War papers, LPA, SCW/1/21. 36 See International papers, LPA, LSI/20/2/3.

37 Speech at Birmingham, 28 Nov. 1937, Dalton papers, 6/2.

${ }^{38}$ Speech, probably Jan. 1939 soon after he was expelled from party, Cripps papers, 483 .

3o Wingate to Cripps, 29 Nov, 1937, Cripps papers, 521 .

40 Minutes of SCC, 16 Dec. 1937, NEC mins.

41 Minutes of SCC, 31 Mar. 1938, NEC mins.

12 Report of the 68th annual congress of the TUC, Plymouth 7-I I Sept. 1937, p. 275.
} 
leaders associated with the transport industry combined with a view to inviting workers to do gratuitous overtime for the cause of the Republic. ${ }^{43}$ Lorries and motor-cycle combinations intended specifically for humanitarian relief were sent to Spain, and Voluntary Industrial Aid also proposed sending agricultural machinery to combat the food shortage. In March $193^{8}$ Pyke wrote to Gillies about the nature of the Spain Campaign Committee, posing the fundamental question: did the committee seek to 'help the Spanish Workers, Trade Unionists and Democrats... to win in the conflict', or was it a body designed only 'to help the sufferers from attack?' Pyke was very bitter:

Would it, for example, prefer to contribute to the protection of the children of Barcelona, Tarragona and Valencia, by providing fighter aeroplanes to drive off the German and Italian bombers, or would it prefer to limit itself to picking up the bits and sending tin milk (sic) to the survivors? ${ }^{44}$

The Spain Campaign Committee did not satisfy the demands of the rank and file and it was left to the Labour Spain Committee to provide the political lead in $193^{8}$. This took the form, primarily, of calling for a national emergency conference on Spain, since the Labour party decision to change the date of its annual conference from autumn to Whitsun left $193^{8}$ with no national meeting of the Labour movement at which the Spanish issue could be raised.

In April $193^{8}$ the Labour Spain Committee organized a conference in London attended by sixty-five divisional labour parties and ten trades councils. The conference arrived at a number of decisions which included a call for an emergency national conference of the Labour party, and a demand for a positive policy from the National Executive for breaking down the arms embargo. ${ }^{45}$ The cry of the conference was 'To save Spain is to save Britain', and Brailsford wrote to George Dallas, who was party chairman, on I I April $193^{8}$ warning him that if the Executive did not act then the rank and file would.

Brailsford's appeal for bold leadership went unheeded. On 12 April 1938 a meeting of the National Executive noted the April 1938 conference and a letter from Brailsford. At the same time it was observed that an article had appeared in Reynolds Netes advocating a 'Peace Alliance'. Once again the association between the Labour Spain Committee and the popular front was established. The following month, on 5 May, the Executive noted, again under the heading 'Peace Alliance and Popular Front' that a communication had been received from the Labour Spain Committee calling for an emergency conference. At this meeting, Cripps asked for the conference to discuss Spain but not the popular front. After a nine to nine vote, Dallas as chairman cast his vote against. Following a further request from the Labour Spain Committee, the Executive finally ruled on 22 June that it would not call an emergency conference but that the position would be kept under review, and only if the international situation made it necessary would such a conference be summoned.

The Labour Spain Committee managed, however, to call a national conference of its own in October $193^{8}$ for which it received supportive recognition from the Now Statesman. ${ }^{16}$ But the conference stressed the cause of the popular front, a message

4 Memorandum to Labour party committee on help for Spain, 2 I Nov. 1937, Cripps papers, 537.

44 Pyke to Gillies, 30 Mar. 1938, Cripps papers, 537.

4 Report on emergency conference on Spain, 9 Apr. 1938, Spanish Civil War papers, $\mathrm{SCW} / 4 / 1$. 46 2 i Oct. 1938. 
hardly designed to evoke sympathy from party leaders who continued to reject the concept, which by the end of 1938 had broadened to include Liberals and dissatisfied Conservatives, in contrast to the Unity Campaign of 1937. Indeed, the Executive was soon to expel Cripps for continued advocacy of the idea. Not surprisingly, therefore, little attention was paid to the October $193^{8}$ conference by the Labour leadership, even though the situation of the Spanish Republican government grew rapidly worse. The Labour Spain Committee sent an embittered telegram to the National Executive on 9 January 1939 protesting at the silence of the party leadership and at the failure of the Spain Campaign Committee to meet for two months at a critical juncture of the war. But still the Executive ruled out any idea of co-operation. However, almost two years after the initial request, they did agree to receive a deputation from the Labour Spain Committee. ${ }^{47}$ On 27 January 1939 Gillies, George Lathan and Philip Noel-Baker met the deputation led by Brailsford, who made five proposals; resolute non-co-operation with the National government's re-armament programme, the setting up of working days for demonstrations in support of the Spanish Republic, co-ordination with other political parties in Britain especially the Liberals and Communists and with the French Socialist party, and finally that a stronger lead be given to divisional Labour parties. Lathan and Baker made it clear that the Executive was not meeting for a month and that in any case the proposals were impracticable. However, it was agreed that the committee's proposals be forwarded along with an invitation to the Executive to attend a conference on Spain. The latter received them on 22 February 1939 , at a time when the Chamberlain government was preparing to recognize Franco as the ruler of Spain. After nearly two years of campaigning the Labour Spain Committee gained access to the National Executive of the Labour party at the very point of collapse of their supposedly common ally, Republican Spain.

The footnote to the struggle of the Labour Spain Committee was provided by the I 939 Southport conference of the Labour party when it met at the new Whitsun date, eighteen months after the previous assembly. In a speech, Ellen Wilkinson urged the condemnation of the National government for its 'one-sided nonintervention' policy and a declaration of support for the Spanish people, along with a call to the National government to protect refugees and prevent savage reprisals by Franco. Then Wilkinson, as a representative of the Spain Campaign Committee, immediately found herself under attack by J. C. Pole and Sybil Wingate of the Labour Spain Committee. Pole accused the Labour party leadership of having failed to make any serious attempt to rally the nation in support of the people of Spain. Sybil Wingate maintained that the success of the campaign to raise funds for relief work had not justified the sacrifice of a political campaign. She observed cynically:

when Franco was massing his army for the last attack on Barcelona this committee (Spain Campaign Committee) met and ... decided to raise more money for the Milk Fund, to organise the sending of Xmas parcels and to issue a Xmas card. ${ }^{48}$

Wilkinson retaliated by accusing Wingate of wanting a general strike, and after some bitter exchanges the amendment proposed by Pole deploring the failure of the National Executive to bring effective aid to the Spanish people was rejected, marking the final defeat of the Labour Spain Committee.

Ironically, the final activities of the committee involved relief work, assisting

425 Jan. 1939, NEC mins.

${ }^{48}$ Report of the $3^{8 t h}$ annual conference of the Labour party, Southport 29 May to 2 June 1939, p. 260, col. I. K. W. Watkins, Britain divided, ends his chapter on the 'British Left' with the debate but does not trace the background to it. He misspells Pole's name as 'Poole', pp. $192 \mathrm{ff}$. 
German and Austrian members of the Thaelmann International Brigade in refugee camps in southern France. ${ }^{49}$ There were difficulties, however, both with the people in Paris organizing the transmission of funds and with the French government. By August 1939 it was decided to wind up the activities of the Labour Spain Committee altogether. ${ }^{50}$

'On the test of Spain', wrote Michael Foot, '... The Bevin-Dalton leadership looked feeble almost to the point of deceit.' ${ }^{51}$ The Labour leaders, however, genuinely believed that they had campaigned hard but had simply failed to convince a sufficient proportion of the population:

If our propaganda has failed, it has failed because we have been unable to arouse the British people in such a way as to make them feel that the cause of Republican Spain was their cause in such a measure that they would take every risk, even the risk of war, to make the Republican cause in Spain prevail..$^{52}$

This was the party secretary's verdict in 1939 and it was supported later in 1943 by Gillies who maintained that 'there was not a majority - or anything like a majority - for our policy in either France or Great Britain'.53 But Sybil Wingate confirmed in 1939 that there was concrete evidence to suggest a majority in favour of Republican Spain when she referred to a recent opinion poll carried out by the British Institute of Public Opinion, which was bringing to Britain the new techniques developed by Gallup in the United States. ${ }^{54}$ In February 1938 a poll asked whether people were in favour of direct retaliatory measures against Franco's 'piracy'. Out of 68 per cent who expressed an opinion, 78 per cent said yes. ${ }^{55}$ In March 193857 per cent expressed sympathy with the Republican government and only 7 per cent for Franco. In October 1938 the same question produced 57 per cent for the Republic and 9 per cent for Franco, but by January 1939 these figures had changed with 72 per cent for the Republic against 9 per cent for Franco. ${ }^{56}$

The Spain Campaign Committee had been most active in 1939 and yet it had failed to discover that there was any majority in support of the Republic, though the polls were published in the News Chronicle, and in spite of its campaigning it had failed to increase that support between March and October I 938. Moreover, when the uncommitted began to come out and express support for Republican Spain partly as a result of the Munich conference - between October $193^{8}$ and January 1939, the Spain Campaign Committee met only once. There is no indication of it having stepped up its activity and it cannot claim, therefore, to have attracted the increased support.

There was, indeed, a marked gap between Labour party rhetoric and its practical achievements. It is true that propaganda must not be seen as a clear expression of party belief and intentions, but the documents issued by the International department

10 Undated letter circulated to members of the LSPC by Brailsford and Pole, in possession of Austen Albu. 5o Austen Albu to Miss Stubbington, 18 Aug. 1939, Albu papers.

s1 Michael Foot, Aneurin Bevan, 1, 1897-1945 (London, 1962), pp. 243 ff.

B2 Draft reply of letter from J. S. Middleton to J. Wilmot, 2 Feb. 1939, Gillies papers, LPA, WG/SPA/569.

"s Gillies to Middleton concerning a letter from Harry Pollitt, I9 May 1943, Middleton papers, LPA, LP/JSM/IMT/4.

st Speech at Southport conference, May i 939, Report, p. 26o, col. 2.

sor this and following poll figures see H. Cantril and M. Strunk, Public opinion 1935- 6 (Princeton, 1951), p. 808.

o At Southport Wingate quoted the figure of 80 per cent - see Report, p. 260. Polls were published 28 Oct. 1938 and 25 Jan. 1939 in News Chronicle. 
of the Labour party and the opinions of its leaders would suggest that the loss of Spain to 'fascist' rule was seen as a major strategic threat. A Labour fly-sheet of December 1938, 'Fighting Our Battle' argued that if Franco won, 'Spain would be in the hands of the dictators who have openly proclaimed their aims of dominating Europe and controlling the Mediterranean. ${ }^{57}$

Labour party concern about this issue was strongly reflected in the parliamentary arena, where the Labour gladiators had performed well by offering repeated challenges to the government at question time, in debate or through the all-party parliamentary committee for Spain. But this was not matched by an extraparliamentary effort of any force sufficient to threaten the composure of the Chamberlain government, even at the end of $1938 .{ }^{58}$ The prime minister could have had little difficulty in rejecting Attlee's appeal for an emergency sitting of parliament in January 1939, when he knew that Labour party leaders had been rejecting appeals throughout 1938 from their own rank and file for an emergency conference on the international situation, on the grounds that it was not sufficiently threatening.

The Labour party was committed to parliamentary means to achieve its objects, and when these failed there was nothing more to be done. Visits to Spain by Labour leaders, including Attlee who, arguably most undeservedly, was to have a company of the British international brigaders named after him, were nothing more than gestures of support which involved no commitment of practical aid for winning the war. ${ }^{50}$

Yet, if the Labour leadership did misjudge the possibilities of public support for Republican Spain, was there an alternative to relief work and did the rank-and-file opposition present it as a positive policy?

The alternative to humanitarian aid was the supply of arms. In April $193^{8}$ the Labour Spain Committee proposed the open export of arms to Spain, in particular anti-aircraft guns. ${ }^{60}$ In the same month, the Spain Campaign Committee considered a proposal to send anti-aircraft guns to Spain, the only example of such an issue being aired. The suggestion that money should be raised to purchase such guns for the defence of open towns in Republican Spain, assuming the grant of a licence by the British government, was rejected by six votes to three. ${ }^{61}$

Undaunted, Brailsford had more far-reaching plans which he had outlined as early as March 1937 when he proposed that Labour and union leaders should escort a cargo of arms for Spain to the docks and defy the government to arrest them. ${ }^{62}$ In April 1938 his proposal was still more imaginative:

Let Attlee or Citrine pack each of them half a machine gun in his suitcase and trust to luck. Said gun shd. carry inscription with names of donors. ${ }^{63}$

57 Spanish Civil War papers, SCW/1/2I.

58 See Jill Edwards, The British government and the Spanish Civil War (London, 1979), pp. 196-9 and Foot, Bevan, I, 289.

50 Thomas, Spanish Civil War, p. 792, footnote 2. Attlee does not mention this particular point in his autobiography As it happened (London, 1954) Pp. 92-5, which gave scant coverage to the issue of Spain.

of Preliminary draft resolution to be put before the conference, Apr. 1938, LSPC papers, LSPC/I $/ 4$.

${ }^{61}$ Minutes of SCC, 26 Apr. 1938, NEC mins. Note that Brailsford had written to George Dallas to propose these ideas on t I Apr. 1938, Spanish Civil War papers, SCW/4/3.

14 Mar. 1937, Reynolds Newes.

63 'Arms plans', draft proposals by H. N. Brailsford, undated but probably beginning of Apr. 1938, Albu papers. In the original the word 'influential' applied to donors but was crossed out. 
Brailsford's idea was that they should travel on a British ship in order to break the embargo on arms supplies. It was intended as a gesture rather than a prelude to any significant supply of arms. But even the gesture was opposed by Cripps in May $193^{8,}{ }^{64}$ and the Labour Spain Committee at the October conference of 1938 rejected as impracticable the resolution from its treasurer to break the embargo by making its own shipment of arms. ${ }^{65}$

Cripps's own position was enigmatic. For a man who drew attention consistently to the plight of the Spanish Republic, who spoke willingly and frequently at fund-raising meetings, he made very little attempt to achieve anything very practical through the Spain Campaign Committee. He was in a unique position to co-ordinate interests, but used the opportunity to pursue the idea of a popular front, often without reference to the interests of Spain. If aid to Spain was the prime issue, then it was tactically naive to associate such aid with the concept of the popular front, even if logically the connexion was unavoidable. ${ }^{68}$

The Labour Spain Committee was guilty of the same error. While it was a sensible political consideration to get all those interested in supporting the Spanish Republic to work together, by making the concept of the popular front a fundamental part of their programme they ruled out the opportunity for compromise. In January I 939, just as they had finally gained access to the National Executive, their chairman, Brailsford, was calling for a protest against the expulsion of Cripps from the Labour party over this very issue. ${ }^{67}$

Labour party policy towards the Spanish Civil War was as torpid and as ambivalent as that of the National government. The party's identification with the cause of the Spanish Republic was never translated into practical aid for winning the war. Whether possible or not, it was never contemplated. The Labour party leadership failed consistently to put principle into practice, while the rank-and-file opposition to party policy, as expressed by the Labour Spain Committee, confused imperatives and failed to effect a radical change of policy.

a4 Cripps to Brailsford, 30 May $193^{8}$, Cripps papers, 52 I.

${ }^{45}$ Labour and Spain - official report of the English conference of Labour parties, 23 Oct. 1938, Cripps papers, 521.

"6ee Patrick Seyd, 'Factionalism within the Labour party: the Socialist League 1932-37' in Asa Briggs and John Saville (eds.), Essays in labour history, III (London, 1977), 204-31, for the suspicion which Cripps generated amongst the Labour leadership.

"7 Brailsford and Pole issued a circular on 2o Jan. 1939 in the name of the LSPC supporting Cripps's memorandum on the popular front and protesting against his expulsion, Albu papers. 